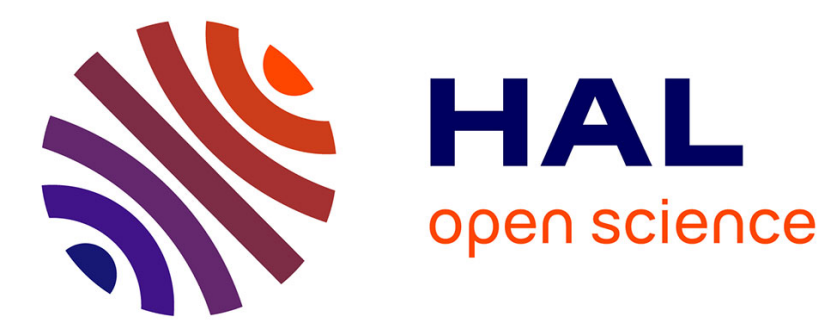

\title{
Monetary Policy Shocks in the new EU members: A VAR approach
}

\author{
Alessio Anzuini, Aviram Levy
}

\section{To cite this version:}

Alessio Anzuini, Aviram Levy. Monetary Policy Shocks in the new EU members: A VAR approach. Applied Economics, 2007, 39 (09), pp.1147-1161. 10.1080/00036840600592866 . hal-00581965

\section{HAL Id: hal-00581965 https://hal.science/hal-00581965}

Submitted on 1 Apr 2011

HAL is a multi-disciplinary open access archive for the deposit and dissemination of scientific research documents, whether they are published or not. The documents may come from teaching and research institutions in France or abroad, or from public or private research centers.
L'archive ouverte pluridisciplinaire HAL, est destinée au dépôt et à la diffusion de documents scientifiques de niveau recherche, publiés ou non, émanant des établissements d'enseignement et de recherche français ou étrangers, des laboratoires publics ou privés. 


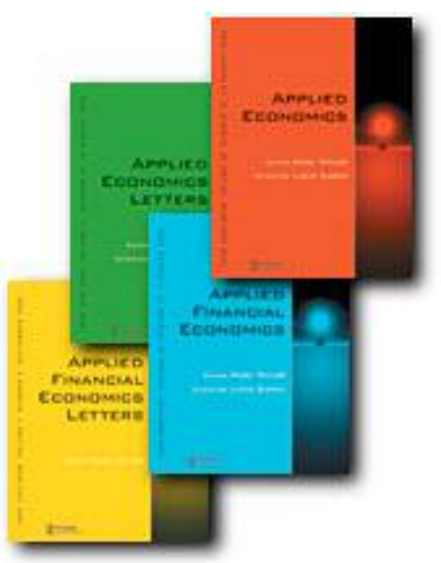

Monetary Policy Shocks in the new EU members: A VAR approach

\begin{tabular}{|r|l|}
\hline Journal: & Applied Economics \\
\hline Manuscript ID: & APE-05-0390.R1 \\
\hline Journal Selection: & Applied Economics \\
\hline $\begin{array}{r}\text { Date Submitted by the } \\
\text { Author: }\end{array}$ & 28-Dec-2005 \\
\hline JEL Code: & $\begin{array}{l}\text { C30 - General < , F41 - Open Economy Macroeconomics <, E52 - } \\
\text { Monetary Policy (Targets, Instruments, and Effects) }<, \text { E44 - } \\
\text { Financial Markets and the Macroeconomy }<\end{array}$ \\
\hline Keywords: & $\begin{array}{l}\text { financial structure, price puzzle, monetary policy shock, identified } \\
\text { VAR }\end{array}$ \\
\hline
\end{tabular}




\title{
Monetary Policy Shocks in the New EU Members: A VAR Approach
}

\begin{abstract}
The paper provides empirical evidence on the effects of monetary policy shocks in the three largest new EU economies: Czech Republic, Hungary and Poland. VAR system estimates show that the co-movement of macroeconomic variables, conditional on a monetary policy shock, is similar across these countries and, despite their lower degree of financial development, not dissimilar to that found for more advanced European economies. While qualitatively similar to the responses observed in the old EU members, the responses of the new members are, on average, weaker.
\end{abstract}

JEL classification: C30, E44, E52, F41.

Keywords: Financial structure, identified VAR, monetary policy shock, price puzzle. 


\section{Introduction ${ }^{1}$}

In May 2004, ten countries joined the European Union (EU): Cyprus, Czech Republic, Estonia, Hungary, Latvia, Lithuania, Malta, Poland, Slovakia, and Slovenia. In the short to medium term, it is expected that these countries will strive for closer integration with EU member states in the monetary field as well, by applying for ERM2 membership and, later, for the adoption of the euro. In this respect, it is desirable that the effects of monetary policy should not differ significantly between old and new members ${ }^{2}$ of the euro area. A similar challenge was faced by the current Economic and Monetary Union members ${ }^{3}$ (EMU) before its creation. A related topic, analysed by a large body of literature in the late 1990s, is whether countries with a diverse economic cycle and financial structure ${ }^{4}$ would be able to adopt successfully a common monetary policy. A standard empirical tool to analyse the effects of the monetary policy on macroeconomic variables is Vector Auto Regressions (VARs). After estimating country-specific VAR systems one can recover the impulse responses and, by comparing them across countries, single out the differences in the effects of monetary policy. VAR analysis had been applied to almost all old EMU members, but, to the best of our knowledge, there are no papers ${ }^{5}$ applying this tool to the new members to assess the differences in recovered impulse responses. Against this background, the main purpose of our paper is to provide econometric evidence on the effects of a monetary policy shock. More specifically, our VAR estimates aim to compare the effects of monetary policy shocks in the Czech Republic, Hungary and Poland and, subsequently, to assess whether the effects differ from the conditional responses which can be observed in other western European ${ }^{6}$ countries. The contribution of the paper is threefold, therefore. First, we estimate VAR systems for the economies of the three largest new members and we recover impulse responses. Second, we compare these responses with those found for the old members. Third, we provide an explanation for the differences in the responses based on the differences between the financial structures of the old and new members.

All VARs are just identified systems and identification is obtained using short-run restrictions, i.e. zeros in the impact matrix. A recursive and a nonrecursive identification scheme are applied to all the estimated systems. We deem that the latter is more appropriate as it does allow the interest rate to react to innovations in the exchange rate within the period and, at the same

\footnotetext{
${ }^{1}$ We thank Fabio Canova, Stefano Neri, Alessandro Rebucci and an anonimous referee for useful suggestions.

${ }^{2}$ This paper is concerned with monetary policy shocks, but there are, of course, other factors that play a crucial role in determining the success and desirability of a monetary union: business cycle synchronization, structural homogeneity, trade integration and factor mobility to cite a few; see, among others, Alesina and Barro (2001).

${ }^{3}$ See, among others, Mojon and Peersman (2001) and Mihov (2001).

${ }^{4}$ Recent studies on this issue are Guiso et al. (1999) and Angeloni et al. (2002).

${ }^{5}$ Jarocinsky (2004) is the only exception. In that paper the author applies Bayesian VAR (identified with a mix of short-run and sign restrictions) with a panel of new and old member countries and provides a comparison of the recovered impulse responses. As correctly argued by the author, the main reason for using Bayesian techniques in this case is the small number of observations available for the new members. We show here that, despite this caveat, by "letting the data speak loud" it is possible to recover reasonable impulse responses for all the new members considered.

${ }^{6}$ Our results are compared with Kim (1999) and Kim and Roubini (2000).
} 
time, allows the interest rate to respond instantly to a monetary policy shock. A comparison between old and new members is obtained by comparing the average responses of both for output and price level, and computing the contribution of the monetary policy shock to output fluctuations. ${ }^{7}$

The econometric results suggest that the macroeconomic variables of the three countries react to a monetary policy shock in the standard way. Following a 1 percentage point increase in interest rates, industrial production declines significantly and persistently in all countries. If we exclude the first part of the 1990 s, in all countries consumer prices tend to decline significantly after roughly one year. As for the exchange rate, in all countries a contractionary domestic monetary shock leads to an appreciation. Using previous studies on monetary transmission in the EU as benchmarks, an important result of this exercise is that, despite the lower level of financial development, in the three new members considered the contribution of a domestic monetary shock to output fluctuation is in line with previous estimates for the four largest EU economies. We conclude that no compelling evidence of asymmetric effects is found either between new and old EU members or among new members.

Three additional results are worth mentioning. The first is that, on average, the responses of macroeconomic variables of the new members are weaker compared with the old members, a result that may be explained by the differences in the financial development of the two groups. The second result is that Poland has the most stable impulse response functions. For this country, the estimated responses are stable over time and across different identification schemes. Third, among the three new members Hungary's responses are the strongest ${ }^{8}$ the responses of the Czech Republic and Poland are the weakest, respectively, in industrial production and prices. However, it is important to note that, even if the identification scheme is the same and the shock is normalised across countries so that comparisons are possible to some degree, confidence bands are generally large enough to suggest that differences in averages may not be significant.

The paper is organised as follows. Section 2 presents the empirical model. Section 3 describes the estimates of the VAR systems, which are carried out separately on each new member state. Section 4 concludes.

\section{The empirical model}

The aim of this exercise is to analyse the effects of a contractionary monetary shock in the new members of the EU. We estimate a five-variable VAR system for each new member considered (i.e. Czech Republic, Hungary and Poland). All estimated VARs are just identified systems. All identifying restrictions are short-run restrictions, i.e. zeros in the impact matrix. All variables are expressed in log levels (except interest rates). Following the literature, we implicitly assume that there is enough co-integration for the variables to be jointly covariance stationary ${ }^{9}$ (Sims, 1990). In all regressions, a complete set of seasonal

\footnotetext{
${ }^{7}$ We only compute the portion of output variance which is due to monetary policy shocks. In a recent contribution, Dibooglu and Kutan (2005) identify different shocks in order to disentangle their contribution to output and price fluctuations.

${ }^{8}$ Note, however, that the estimates for Hungary contain a very high degree of uncertainty.

${ }^{9}$ Most papers applying VAR in the field of monetary economics use variables in level, regardless of the identification scheme. In these papers the ultimate goal is to derive the
} 
dummy variables is included in order to capture any seasonality effect. The lag length of each system is chosen so as to strike a balance between two needs: eliminating the autocorrelation of the residuals and preserving as many degrees of freedom as possible. ${ }^{10}$ We chose to perform a Ljiung-Box test and increase the number of lags up to the point where the autocorrelation was not significant at a 5 per cent level. Since the Ljiung-Box test has a strong small sample bias, we always evaluate the lag structure obtained from this test against a set of alternatives using AIC (Akaike Information Criterion) and SBC (Schwartz Bayesian Criterion). In the VAR literature ${ }^{11}$ no consensus has emerged on the assumptions needed to identify a monetary policy shock. However, it is possible to distinguish between two groups of identification schemes based on short-run restriction: the recursive structure as in Christiano, Eichenbaum and Evans (1998) and the non-recursive structure as in Kim (1999). Both identification schemes are designed to recover only the effects of a monetary policy shock. In both schemes a contractionary monetary policy shock is a positive innovation in the nominal interest rate and the row in which the nominal interest rate appears as endogenous variable is interpreted as a reaction function ${ }^{12}$ of the monetary authorities. While in the recursive structure the Wold order of the variables implicitly assumes that monetary authorities choose the interest rate by looking at the current level of prices and output and that output and the price level do not change in the impact period but react only with a one-period delay, in the non-recursive identification approach (Structural VAR) each row has its own interpretation (see Kim, 1999) and it is assumed that owing to an information delay monetary authorities do not see the current value of prices and output when choosing the interest rate. ${ }^{13}$

More precisely, the variables are placed in the vector $y_{t}$. The structural form is:

$$
C(L) y_{t}=\eta_{t}
$$

where $C(L)$ is a polynomial matrix in the lag operator. Let be $V C V\left(\eta_{t}\right)=\Lambda$, a diagonal matrix with the variances of the structural shocks as elements. We estimate (ignoring predeterminates) the reduced form:

$$
y_{t}=A(L) y_{t-1}+\varepsilon_{t}
$$

where $A(L)$ is a polynomial matrix in the lag operator and $V C V\left(\varepsilon_{t}\right)=\Sigma$ and $\eta_{t}=C_{0} \varepsilon_{t}$, therefore $\Sigma=C_{0}^{-1} \Lambda C_{0}^{-1^{\prime}}$.

In order to obtain a just identified system we need $\frac{n \times(n-1)}{2}$ restrictions. The

\footnotetext{
impulse response functions. In fact, if one can recover a stable set of impulse responses this may be considered an indication of the joint stationarity of the variables in the system.

${ }^{10} \mathrm{We}$ always use a symmetric lag structure; on the implications of an asymmetric lag structure see Kim and McMillin (2003).

${ }^{11}$ A comprehensive survey on the topic can be found in Christiano, Eichenbaum and Evans (1998).

${ }^{12}$ The row in which the interest rate appears on the left-hand side can be regarded as the reaction function of the monetary authority; such an interpretation is standard in this literature, irrespective of the identification scheme used.

${ }^{13}$ Sims and Zha (1995) made similar assumptions.
} 
recursive identification scheme is:

$$
\left[\begin{array}{c}
\eta_{t}^{1} \\
\eta_{t}^{2} \\
\eta_{t}^{3} \\
\eta_{t}^{\text {monetary }} \\
\multicolumn{1}{c}{\eta_{t}^{5}}
\end{array}\right]=\left[\begin{array}{ccccc}
1 & 0 & 0 & 0 & 0 \\
g_{21} & 1 & 0 & 0 & 0 \\
g_{31} & g_{32} & 1 & 0 & 0 \\
g_{41} & g_{42} & g_{43} & 1 & 0 \\
g_{51} & g_{52} & g_{53} & g_{54} & 1
\end{array}\right]\left[\begin{array}{c}
\varepsilon_{t}^{c p i} \\
\varepsilon_{t}^{i p} \\
\varepsilon_{t}^{m} \\
\varepsilon_{t}^{i} \\
\varepsilon_{t}^{c p}
\end{array}\right]
$$

where the variables in the vector $y_{t}=(c p i, i p, m, i, c p)$ are, respectively, prices, industrial production, money, interest rate and commodity prices. The $C_{0}$ matrix identifies the relation between the structural disturbances $\eta_{t}$ and the reduced-form residuals $\varepsilon_{t}$. In the non-recursive scheme $C_{0}$ takes the form:

$$
\left[\begin{array}{c}
\eta_{t}^{\text {monetary }} \\
\\
\eta_{t}^{2} \\
\eta_{t}^{3} \\
\eta_{t}^{4} \\
\eta_{t}^{5}
\end{array}\right]=\left[\begin{array}{ccccc}
1 & g_{12} & 0 & 0 & g_{15} \\
g_{21} & 1 & g_{23} & g_{24} & 0 \\
0 & 0 & 1 & g_{34} & 0 \\
0 & 0 & 0 & 1 & 0 \\
g_{51} & g_{52} & g_{53} & g_{54} & 1
\end{array}\right]\left[\begin{array}{c}
\varepsilon_{t}^{i} \\
\varepsilon_{t}^{m} \\
\varepsilon_{t}^{c p i} \\
\varepsilon_{t}^{i p} \\
\varepsilon_{t}^{c p}
\end{array}\right]
$$

where a $g_{i j}$ means that the coefficient is not constrained. The first line is a money supply equation modelled as a reaction function of the monetary authority; ${ }^{14}$ the second line is a standard money demand equation; the third and fourth lines encapsulate the hypothesis of price stickiness or adjustment cost; the fifth line is an arbitrage equation. This scheme is particularly adequate when dealing with small open economies because it allows interest rates to be set by monetary authorities, taking exchange rate movements into account (which is consistent with the so-called "fear of floating", see Calvo and Reinhart 2002).

In both schemes the last variable is the world export price in domestic currency, i.e. the nominal exchange rate multiplied by the world export price in US dollars. The inclusion of the latter variable is motivated, in the VAR literature, by the need for some control of imported inflation or, more generally, to control for an endogenous increase in the interest rate. ${ }^{15}$ Since we are dealing with very small open economies we will interpret the movements of the world export price in US dollars, conditional on a monetary shock, as the movement of the nominal exchange rate. ${ }^{16}$ Both identification schemes allow nominal exchange rates to react immediately to the monetary shock, but only the second scheme assumes that monetary authorities look at the contemporaneous value of the exchange rate while choosing the nominal interest rate. In order to rule out changes in the transmission mechanism of a monetary policy shock, we would like to deal with economies for which exchange rate arrangements do not change in the estimation period. Unfortunately, all the small open economies considered in this paper have modified their exchange rate regime in the sample period used for the estimates (see Table 1).

This last consideration may cast some doubts on the plausibility of a stable linear model for new EU members. However, although a model with stochastic

\footnotetext{
${ }^{14}$ We normalise the shock to a 1 per cent increase in interest rates.

${ }^{15}$ We also estimate the systems using real effective exchange rates instead of commodity prices.

${ }^{16}$ This interpretation is supported by the fact that, when included in the systems, the real exchange rate appreciates while the price level decreases.
} 
regime switches or time-varying parameters ${ }^{17}$ might be more appropriate for transition economies, the estimates in this paper are of some interest as they summarise relations in the data averaged over different states. Moreover, it is not completely clear how the exchange rate regime affects the transmission of a monetary shock in less industrialised countries (see, for example, Canova, 2003)..$^{18}$

In all the systems we identify only a monetary shock, and impulse response functions have a 48-month horizon. Confidence bands at 68 per cent significance level, calculated by means of a Bayesian Montecarlo experiment (Sims and Zha, 1999), are plotted for all estimates. ${ }^{19}$ We use monthly data covering the period 1993-2002. Despite their lack of financial development, in all the new members, conditional on a monetary shock, macroeconomic variables display standard behaviour: industrial production declines, the exchange rate tends to appreciate and the price level declines.

\section{The expected effects of monetary shocks}

Before presenting the results of our estimates, we discuss the expected responses of the macro variables conditional on a monetary policy shock. The effectiveness of monetary policy is closely related to the transmission of a monetary impulse from the central bank's policy rates to the money market and then to the bond market and other fixed-income interest rates. The transmission from the money market to the lending rates applied by banks to non-banks is the other side of the story. The degree of development of the financial markets and their proper functioning are therefore crucial for the propagation of monetary impulses.

The effect of interest rates on the exchange rate is obviously another important channel. In the theoretical literature ${ }^{20}$ there are two major classes of models used to study the effects of a monetary shock: "limited participation models" and "money in the utility function models". In both classes, following a contractionary monetary shock the interest rate increases, prices decrease and output does not increase; it is worth noting, however, that similar effects are reached through very different transmission mechanisms.

In a "limited participation" model, following an injection of liquidity by the authority the available funds that banks can lend to firms increase, firms can raise investment and the increased investment boosts economic activity. In the real world this mechanism is represented by the credit channel. Since we expect the credit channel to play a central role in firms' response to changes in monetary policy, we use the share of bank loans to total liabilities of the corporate sector as an indicator of firms' expected reaction to interest rate changes, i.e. the higher this share is, the more the business sector should be

\footnotetext{
${ }^{17}$ While estimating a VAR with time-varying parameters is a relatively easy task using standard Kalman filter techniques, obtaining impulse response functions using short-run restrictions in a model with many states is not straightforward (see Sims and Zha, 2002). Moreover, to the best of our knowledge, no estimates for the old members obtained using this methodology are available for comparison.

${ }^{18}$ In that paper the author shows, among other things, that the exchange rate regime does not matter for the transmission of US shocks to Latin American economies.

${ }^{19}$ This method produces confidence intervals very similar to those obtained using the procedure proposed by Kilian and Chang (2000), which corrects for small sample bias.

${ }^{20}$ See Walsh (2001) for an extensive analysis of monetary models.
} 
affected by monetary impulses. Hungary has the highest share at 34 per cent. It is worth noting that this figure is high not only compared with the other two new members considered (27.2 per cent for the Czech Republic and 19.2 per cent for Poland) but also compared with the EU average (24.8 per cent).

In a "money in the utility function" model some nominal rigidity is usually introduced in order to obtain real effects from a nominal shock; price stickiness, for example, is a standard assumption when a positive co-movement of nominal and real interest rates is desired. In this class of model, as in most microfounded models, the interest rate plays a role because it enters the Euler equation, which gives the optimal consumption path for the representative household. An increase in the interest rate increases the cost of today's consumption in terms of future consumption and therefore the optimal household's response is a decrease in today's consumption. Since those models are usually demand driven, a contraction in one component of demand reduces real activity. In the real world this mechanism is difficult to isolate. An increase in the interest rate may impact directly on expected future income, and indirectly on consumption, if the share of interest payments to total payments is a non-negligible part of households' balance sheets. For this reason we use this share as an indicator of the expected reaction of households, i.e. the higher this share, the greater the impact of monetary policy. In the new members household debt is very low compared with the EU average (60 per cent of GDP). In the Czech Republic and Poland loans to households account for 8 per cent of GDP and in Hungary 6 per cent.

At an aggregate level, the new members still lag well behind the old EU members in terms of financial development. Their ratios of financial assets to GDP are well below the EU average, with the Czech Republic displaying a higher ratio than the other two countries. In all the new members the socalled "Financial Intermediation Ratio" (the ratio of assets held by financial institutions to assets held by all other sectors of the economy) is lower than the EU average, again with the Czech Republic closest to the EU average. On a more disaggregated level the picture is slightly different. The structure of firms' financial liabilities suggests that Hungarian firms raise risk capital to an extent similar to EU members: the fraction of equity in total liabilities in Hungary is 56.1 per cent, very close to the EU average of 60.6 per cent. The share is lowest in the Czech Republic (39.5 per cent), whereas Poland's share is 42.9 per cent. Even if deposits are households' favourite assets for carrying wealth over time among the new members, the percentage of "shares and mutual funds" of Hungarian households (34.9 per cent) is very close to the EU average (33.5 per cent).

If we take those indicators as a proxy of financial development, we can say that the three largest new members have relatively low levels of financial depth and financial intermediation. Moreover, an important role is played by nonresidents. At an aggregate level, the financial development of those countries is still behind that of the EU. At a sectoral level the behaviour of firms and households in Hungary is less distant from the EU average. However, despite the lack of financial development, we argue that in the three new members the effects of a contractionary monetary policy shock are qualitatively not dissimilar to that found in the more advanced economies and not dissimilar from the predictions of a large class of theoretical models. 


\subsection{Czech Republic}

For the Czech Republic three lags seem sufficient to capture the dynamics of the system. Figure 2 shows the impulse response functions (IRF) obtained with the non-recursive scheme using the entire sample (1993:01-2002:01). After a 1 percentage point increase in interest rates, money decreases, thus displaying the classical liquidity effect $;{ }^{21}$ the exchange rate appreciates, ${ }^{22}$ reaching a peak (-0.8 per cent) within a year. Industrial production declines following hump-shaped trend, with a negative peak of 0.16 per cent; prices decline ${ }^{23}$ persistently to a minimum of 0.34 per cent.

Figure 3 shows the responses of the same system after we have replaced commodity prices with real effective exchange rates. All previous results hold; moreover, the real exchange rate ${ }^{24}$ appreciates and, since prices do not increase, we attribute this to nominal exchange rate appreciation. ${ }^{25}$ Figure 4 shows the impulse responses obtained using the recursive identification scheme. ${ }^{26}$ While industrial production and exchange rates ${ }^{27}$ move in the expected direction, money and prices move significantly in a counter-intuitive manner, i.e. we obtain no liquidity effect and a price puzzle. For the Czech Republic it is therefore crucial to allow interest rates to respond to contemporaneous innovations in the exchange rate if one wants to identify monetary policy shocks. ${ }^{28}$

In general, two channels are operating at the same time: the interest rate channel (and, indirectly, the credit channel) and the exchange rate channel. An increase in the interest rate depresses economic activity through tighter credit conditions (limited participation model), while the higher interest rate attracts foreign funds and appreciates the currency. The nominal appreciation of the currency may depress the economy even more if, due to some stickiness, it affects the relative price of domestic and foreign goods. Overall, the shape of the dynamic responses of the Czech Republic are strikingly similar to what we observed in more advanced economies such as the G-7.

\subsection{Hungary}

In the case of Hungary four lags seem sufficient to capture the dynamics of the system. When we use the entire sample, the confidence bands easily include the zero line. Point estimates are surrounded by considerable uncertainty and for the first few quarters we get a price puzzle. ${ }^{29}$ Using the second part of the

\footnotetext{
${ }^{21}$ See Kim and Ghazali (1999) for some recent evidence of the presence of liquidity effects in the G-7 countries.

${ }^{22}$ Although not at impact, so that Uncovered Interest Parity (UIP) is violated.

${ }^{23}$ Not significantly, due to the large uncertainty.

${ }^{24}$ Estimates start from 1994:01 for reasons of data availability.

${ }^{25}$ In this case, however, besides the first two periods, exchange rate movements are in line with the prediction of the UIP.

${ }^{26}$ This system is identical to the one used in Figure 2 except for the identification scheme.

${ }^{27}$ Exchange rates always respond in the expected direction; this is probably due to the high elasticity of portfolio investment.

${ }^{28}$ Indeed, using the second part of the 1990s (1997:06-2002:01) it is possible to recover resonable dynamics for the IRF even with the recursive identification scheme. However, using this subsample would leave 55 observations to estimate a five-variable VAR of order three with a full set of dummy variables, which is likely to generate small sample bias.

${ }^{29}$ In the first part of the 1990s the price system in Hungary was mostly based on administrative controls; those controls were removed only gradually and the price formation mechanism started to work as in a market economy.
} 
1990s we are confronted with more reasonable dynamics. ${ }^{30}$ Figure 4 shows IRF obtained with the non-recursive scheme using the sample (1995:04-2002:01). All variables move significantly in the expected directions. ${ }^{31}$ After a 1 percentage point increase in interest rates, the exchange rate strongly appreciates ${ }^{32}$ (by 3.4 per cent). Industrial production declines with a negative peak of 2 per cent. Prices decline very persistently, ${ }^{33}$ reaching a minimum of 0.8 per cent. Using real effective exchange rates the main results still hold. ${ }^{34}$ The use of the nonrecursive identification scheme does not seem particularly problematic in this case (see Figure 5).

\subsection{Poland}

For Poland we were not able to estimate an equation without serial correlation until we included the fifth lag. Figure 8 shows the IRF obtained with the nonrecursive scheme using the entire sample (1993:01-2002:01). After a 1 percentage point increase in interest rates, all variables move in the expected direction. ${ }^{35}$ Prices decline significantly and persistently $(0.3$ per cent is the negative peak after roughly 15 months); industrial production also declines slightly (0.4 per cent). An explanation for this result is suggested by Bednarski and Osinski (2002). They argue that the weak transmission is due to two peculiarities of the Polish banking system: excess liquidity and unwillingness to cut credit when monetary policy is tightened. Excess liquidity is defined as a high level of banks' holdings of central bank debt. The strong capital inflow made the commercial banks less dependent on the central bank. The unwillingness to cut credit is mainly reflected in the use of securities as buffer stock: due to large holdings of securities, banks can reduce their fixed-income portfolio instead of cutting credit following a contractionary monetary shock. In this case too the exchange rate appreciates and the excess returns implied by the co-movement of nominal exchange rate and interest rate are not consistent with the UIP. Using a real effective exchange rate (Figure 9) does not modify the main results, and nor does use of a recursive identification scheme (Figure 10).

\subsection{Overview of results}

The impulse responses of the new members are consistent with a large class of theoretical models, qualitatively similar to those found for western European countries, but one feature stands out: on average, the responses of new members to a monetary policy shock are smaller than those found for old members

\footnotetext{
${ }^{30}$ Of course, this evidence does not prove that the price puzzle was due to the presence of administrative controls. Still, the removal of those controls makes it more likely that the response of prices to monetary policy shock will be in the expected direction.

31 The exception being money at impact.

${ }^{32}$ Again, however, the hump-shaped response of the exchange rate and the dynamic response of interest rates are not consistent with UIP.

${ }^{33}$ The high persistence may be attributed to the overall sluggishness of the Hungarian economy.

${ }^{34}$ Note, however, that in this case the real appreciation is not significant.

${ }^{35}$ Although not significantly in the case of money.
} 
(see Table 2) ${ }^{36}$. Our finding of weaker responses is not surprising, ${ }^{37}$ once the degree of financial development is taken into account. In these countries total financial assets are in the range of 2.5 to 4.5 times GDP, which is far behind the EU average of 8 times GDP. The new members have a low level of financial intermediation (measured as the ratio of financial assets held by financial institutions to financial assets held by all other sectors). Moreover, at the sector level, a significant role is played by foreigners in bank ownership (close to 70 per cent of bank assets) and a large share of total bank credit is granted to domestic firms directly by banks located abroad. The low degree of financial depth and intermediation may explain the weakness of the standard interest rate channel. The equity price channel may be weak due to low stock market capitalization (between 13 and 19 per cent compared with 46 and 165 per cent for the EU). Since bond markets are as little developed as equity markets the overall effect on firms' balance sheets ${ }^{38}$ is likely to be weak. Financial assets held by the household sector range from 55 to 83 per cent of GDP, which is considerably lower than the EU average of 232 per cent. Therefore wealth effects operating through the impact of interest rates on equity prices are likely to be weak too.

Table 3 shows the variance decomposition for the four main European economies, as estimated by Kim (1999), together with our estimates for the three new members. ${ }^{39}$ The table suggests that among the new members considered the contribution of the domestic monetary shock to output fluctuation is, on average, probably not statistically different from that of the old members. The fact that the responses in the new members display a similarity with the EU's old members is important because this makes the case of a particularly strong asymmetry in the effects of monetary policy very unlikely. Once those countries adopt the euro they will give up their monetary sovereignty and the exchange rate channel will weaken significantly. The optimum currency area literature suggests that the cost of giving up those instruments should be lower the higher the symmetry in response to a common shock. Since no strong evidence of asymmetry emerges in our exercise, this would suggest that the cost of entering may be relatively low. A similar conclusion is reached in Frenkel and Nickel (2002), who analyse the differences in the effects of demand and supply shocks on EMU and new EU members.

\section{Conclusions}

The financial accounts of the Czech Republic, Hungary and Poland provide a picture of a private non-financial sector that is, not surprisingly, financially less mature than the EU average. Despite the low degree of financial development, the econometric results suggest that the co-movement of macroeconomic variables in the new members conditional on a domestic monetary shock is not

\footnotetext{
${ }^{36}$ The data attributed in the table to Kim (1999) and to Kim and Roubini (2000) are our own calculations based on their papers.

${ }^{37}$ Jarocinski (2004) also finds that in the short run monetary transmission is weaker in the new members than in Western Europe. In the longer run, however, he finds a stronger effect on prices and output in the new members than in Western Europe.

${ }^{38}$ See Bacchetta and Ballabriga (2000) for a study on the link between banks' balance sheets and monetary policy.

${ }^{39}$ Variance decompositions are derived from the VAR systems identified with a non-recursive scheme in which commodity prices are used.
} 
different from the standard behaviour we would expect, at least when we exclude from the sample the first years of the transition. Following a 1 percentage point increase in interest rates, in all the three countries considered industrial production declines significantly. The impact of monetary policy on the exchange rate always has the expected sign. Presumably this is due to a high elasticity of portfolio investment to the interest rate differential. We find no evidence of counter-intuitive effects of a monetary policy shock in these economies. The contribution of monetary policy to business cycle fluctuations does not differ too much from that observed in current EU members. While qualitatively very similar to those of the old members, however, the responses of the new member economies are quantitatively weaker. The lower level of financial development may help to explain this gap.

The main caveat of our analysis is that the number of observations in our time series is small. Even if some caution is required in interpreting our results, it is possible to argue that in the new members the monetary policy transmission mechanism operates in a way that is fairly similar to the one observed in the old members. The absence of strong asymmetries between old and new members suggests that the cost of the adoption of a common monetary policy may be relatively limited. 


\section{Appendix: Data description}

Unless otherwise indicated, the source of the data used for the econometric estimates is the IMF's International Financial Statistics. Specifically:

Industrial production

Czech Republic: 935..66; Hungary: 944..66; Poland; POIPTOT.H (Source: Thomson Financial Datastream)

Consumer prices

Czech Republic: 935..64; Hungary: 944..64; Poland: 964..64

Interest rate

Czech Republic: 935..60b (three-month interbank interest rate); Hungary: HNINTER3 (Source: Thomson Financial Datastream; three-month interbank interest rate); Poland: 964..60b (three-month interbank interest rate)

Monetary aggregates

Czech Republic: 935351 (money + quasi money); Hungary: HNM2....A (Source: Thomson Financial Datastream; M2); Poland: 964351 (money + quasi money)

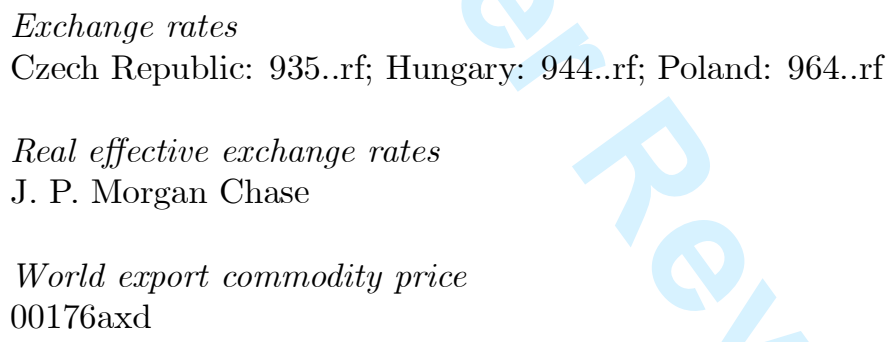

Exchange rates

Czech Republic: 935..rf; Hungary: 944..rf; Poland: 964..rf

Real effective exchange rates

J. P. Morgan Chase

World export commodity price

00176axd

World export commodity prices in terms of domestic currency

This variable is constructed by multiplying the exchange rate (defined as the amount of domestic currency needed per US dollar) by the world commodity price in US dollars. 


\section{References}

[1] Alesina, A. and R. Barro (2001), Currency unions, Stanford, CA: Hoover Institution Press.

[2] Angeloni, I., A. Kashyap, B. Mojon and D. Terlizzese (2002): "Monetary Transmission in the Euro-Area: Where Do We Stand?", European Central Bank, Working Paper No. 114, January.

[3] Bacchetta, P. and F. Ballabriga "The Impact of Monetary Policy and Bank's Balance Sheets: Some International Evidence", Applied Financial Economics, Vol. 10, No. 1, 15-26.

[4] Bednarski, P. and J. Osinski (2002): "Financial Sector Issues in Poland", in ECB (2002).

[5] Calvo, G. and C. Reinhart (2001), "Fear of floating", Quarterly Journal of Economics, Vol. 117 No. 2, 379-408.

[6] Canova, F. (2003): "The transmission of US Shocks to Latin American Economies", CEPR Discussion Paper No. 3963.

[7] Christiano, L., M. Eichenbaum and C.L. Evans, (1998): "Monetary Policy Shocks: What Have We Learned and to What End?", NBER Working Paper No. 6400.

[8] Dibooglu, S. and A. M. Kutan (2005): "Sources of inflation and Output Movements in Poland and Hungary: Policy Implications for Accession to the Economic and Monetary Union", Journal of Macroeconomics, 27, 107131.

[9] EU Commission (2002): "Evaluation of the 2002 pre-accession economic programmes of candidate countries", European Economy Enlargement Papers No. 14, November.

[10] Frenkel, M. and C. Nickel (2002): "How Symmetric Are the Shocks and the Shock Adjustment Dynamics Between the Euro Area and Central and Eastern European Countries?", IMF Working Paper 02/222.

[11] Guiso, L., A. K. Kashyap, F. Panetta and D. Terlizzese (1999): "Will a Common European Monetary Policy have Asymmetric Effects?", Economic Perspectives, Federal Reserve Bank of Chicago, 5675.

[12] Ihnat, P. and P. Prochazka (2002): "The Financial Sector in the Czech Republic: an Assessment of its Current State of Development and Functioning", in ECB (2002).

[13] Jarocinski, M. (2004): "Responses to Monetary Policy shocks in the East and the West of Europe: A Comparison", Studies and analyses 287, Centre for Social and Economic Research.

[14] Kilian, L. and P. L. Chang (2000): "How Accurate are Accurate are Confidence Intervals for Impulse Responses in large VAR models?", Economic Letters, 69, 299-307. 
[15] Kim, B J. C.and N. A. Ghazali (1999): "Has the Effects of Money Shocks on Interest Rates Really Vanished? Further evidence on the liquidity effect", Applied Economics, Vol. 31, No. 6, 743-754.

[16] Kim, K and W.D. McMillin (2003): "Estimating the Effects of Monetary Policy Shocks: Does Lag Structure Matter?", Applied Economics, Vol. 35, No. $13,1515-1526$.

[17] Kim, S. (1999): "Do Monetary shocks matter in the G-7 countries? Using common identifying assumptions about monetary policy across countries", Journal of International Economics, No. 48, 387-412.

[18] Kim, S. and Roubini N. (2000): "Exchange rate anomalies in the industrial countries: A solution with a structural VAR approach", Journal of Monetary Economics, 45:561-568.

[19] Mihov, I. (2001): "Monetary Policy Implementation and Transmission in the European Monetary Union", Economic Policy, No. 33, 371-406.

[20] Mojon, B. and G. Peersman (2001): "A VAR description of the effects of monetary policy in the individual countries of the Euro area", ECB Working Paper no. 92.

[21] Oesterreichische Nationalbank (2002): Focus on Transition, 58-71.

[22] Sims, C.A. (1990): "Inference for Multivariate Time Series Models with Trend", Econometrica, Vol. 58, No. 1, 113-144.

[23] Sims, C.A. and T. Zha (1995): "Does Monetary Policy Generate Recessions", Manuscript, Yale University.

[24] Sims, C.A. and T. Zha (1999): "Error Bands for Impulse Responses", Econometrica, Vol. 67, No. 5, 1113-1155.

[25] Sims, C.A. and T. Zha (2002): "Macroeconomic Switching", MIMEO.

[26] Wagner, N. and D. Yakova (2001): "Financial Sector Evolution in the Central European Economies: Challenges in Supporting Macroeconomic Stability and Sustainable Growth", IMF Working Paper No. 01/141, September.

[27] Walsh, Carl E. (2001): "Monetary Theory and Policy", MIT Press.

[28] Zoli, E., H. Tang and I. Klytchnikova (2000): "Banking Crises in Transition Economies: Fiscal Costs and Related Issues", World Bank Working Paper No. 2484, November.

[29] Zsamboki, B. (2002): "The financial sector in Hungary", in ECB (2002). 

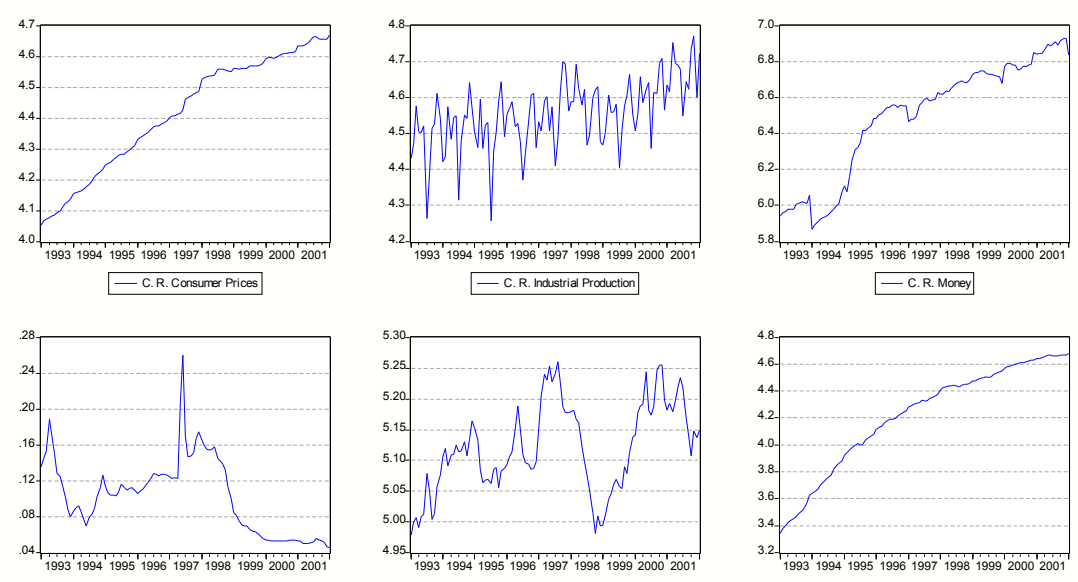

-C.R. Commodityprices
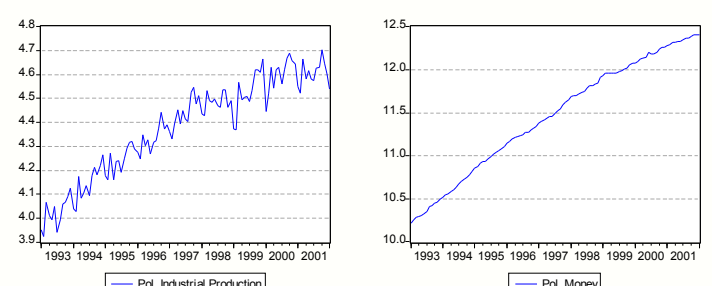

- Pol. Consumer rives

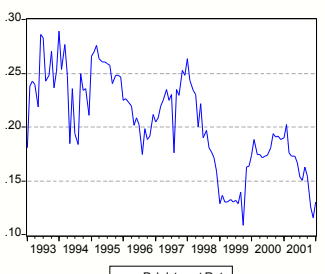

- Pol. Indstrtial Production

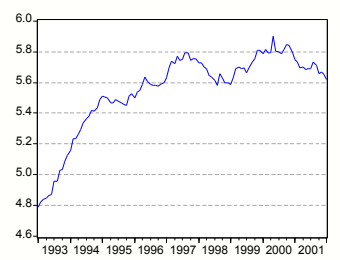

-Pol.Commodityricices

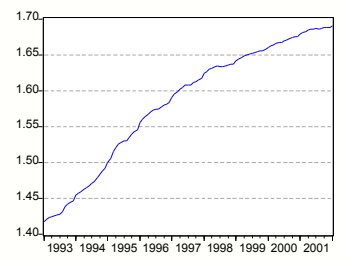

-Pod. Interestrade
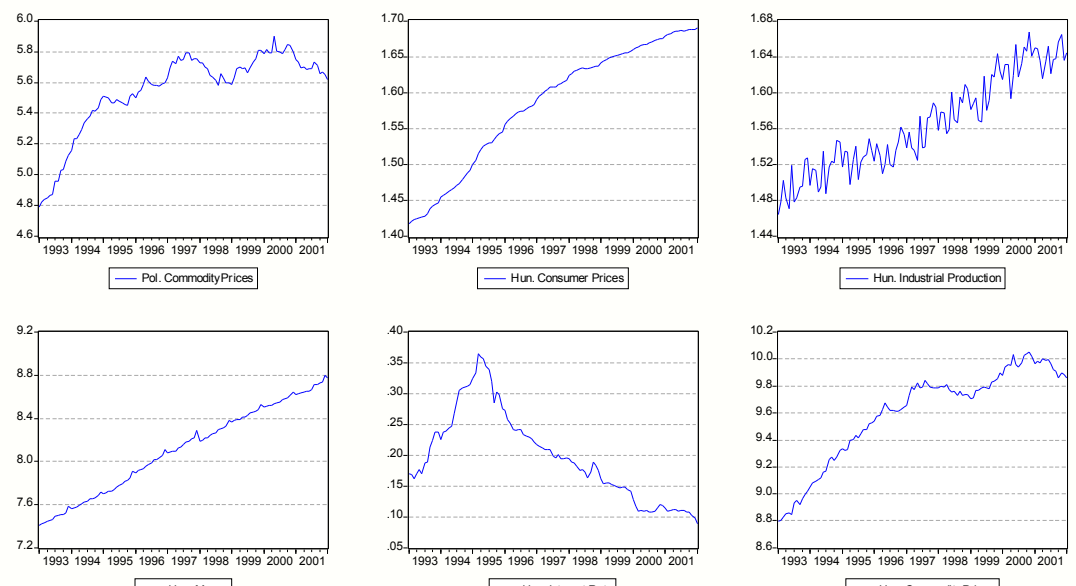

- Hun Corsumer Prices
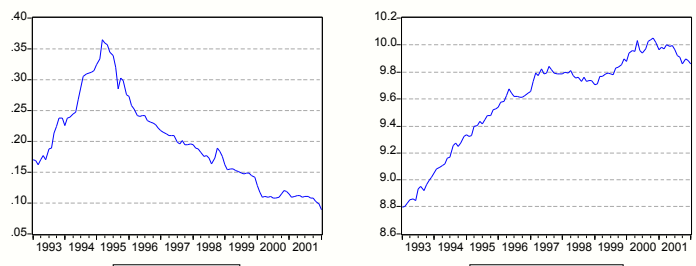

Figure 1: Endogenous variables. All variables, except interest rates, are in logs. 
Monetary Shock (Czech Republic)
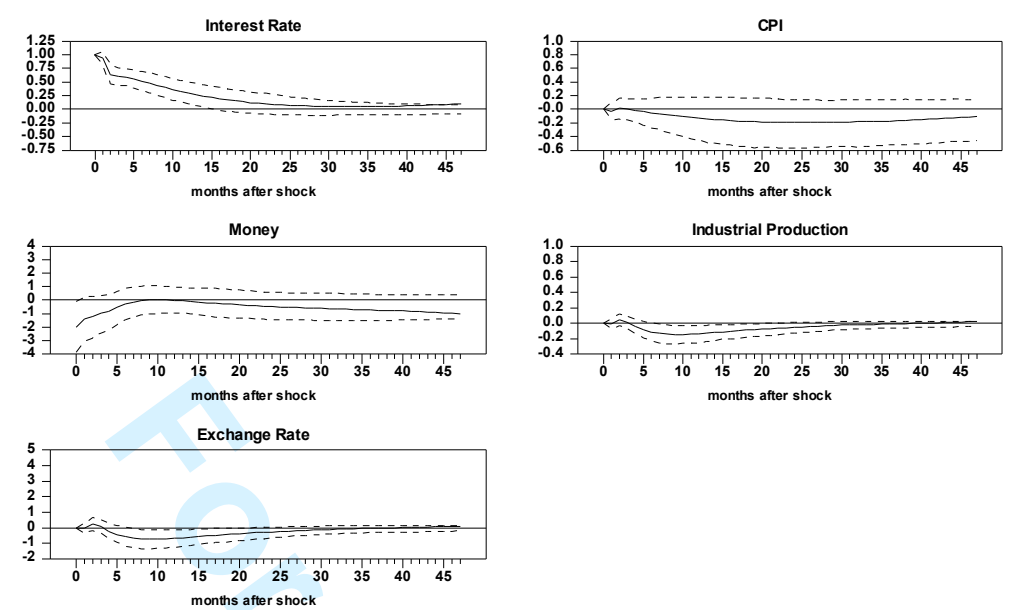

Figure 2: Non-recursive identification scheme, sample period 1993:01-2002:01.

\section{Monetary Shock (Czech Republic)}
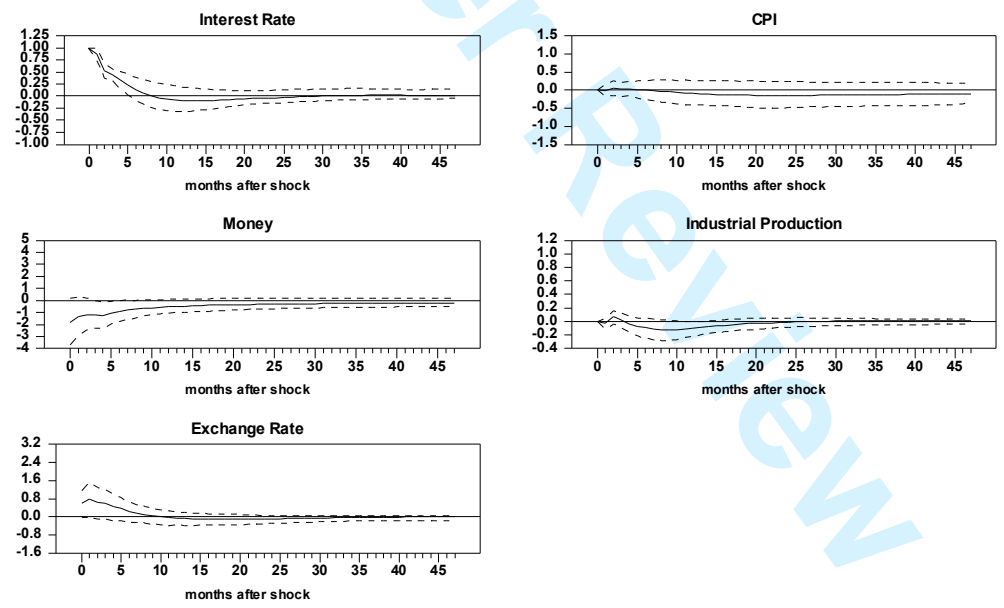

Figure 3: Non-recursive identification scheme, sample period 1993:01-2002:01; real effective exchange rate. 
Monetary Shock (Czech Republic)
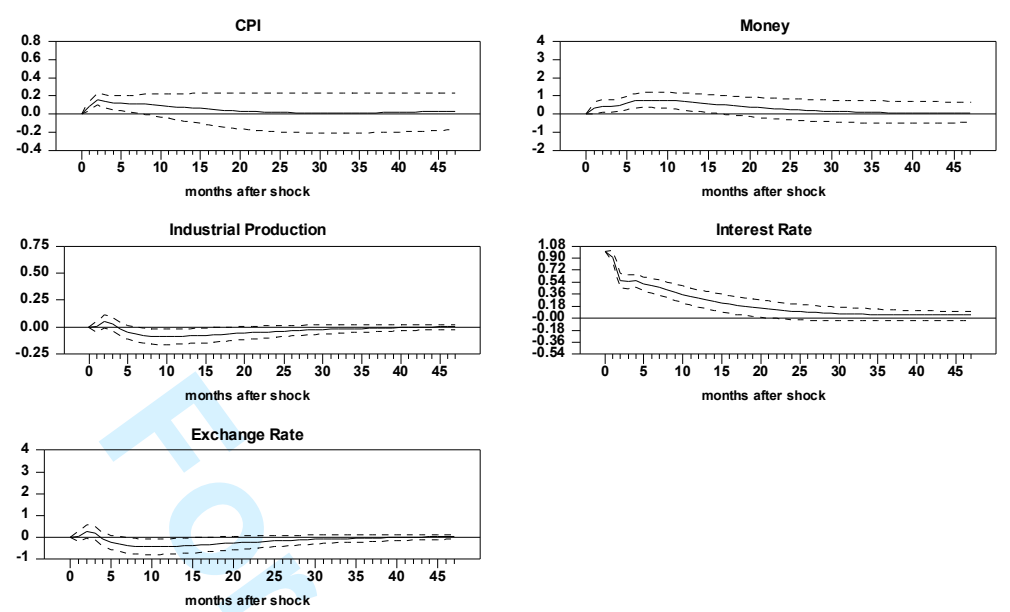

Figure 4: Recursive identification scheme, sample period 1993:01-2002:01

\section{Monetary Shock (Hungary)}
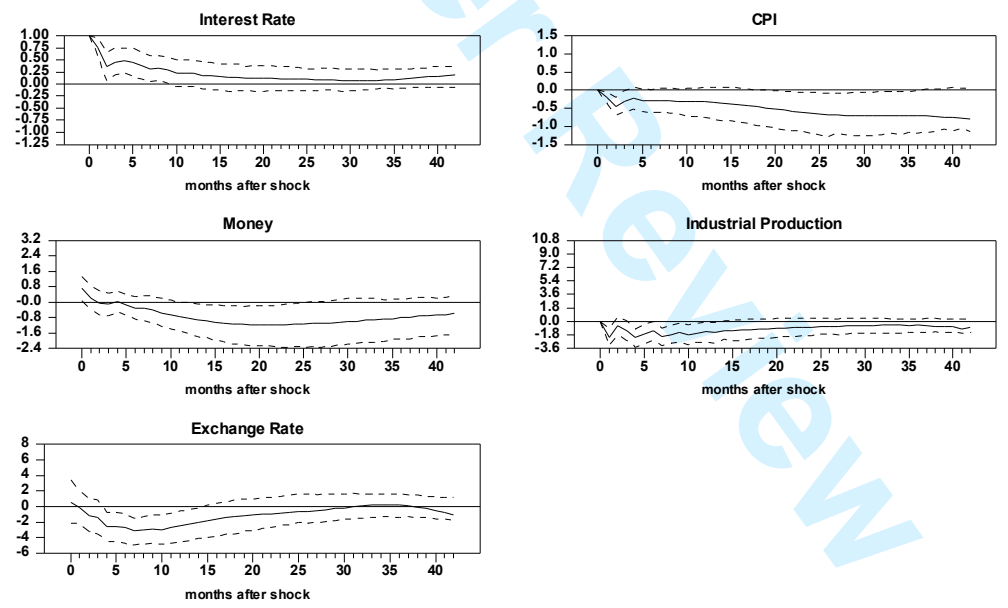

Figure 5: Non-recursive identification scheme, sample period 1995:04-2002:01. 
Monetary Shock (Hungary)
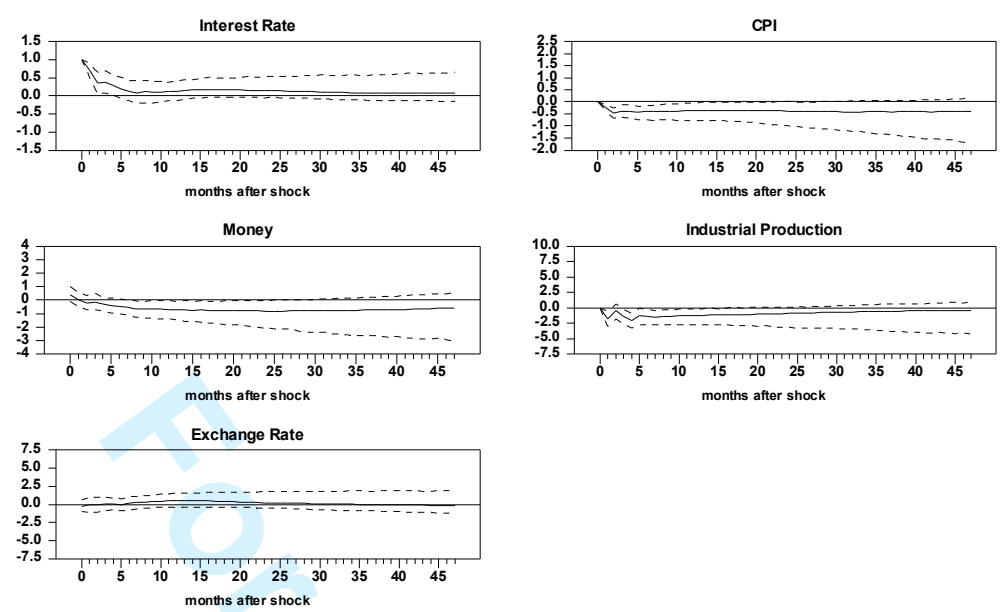

Figure 6: Non-recursive identification scheme, sample period 1995:04-2002:01; real effective exhange rate.

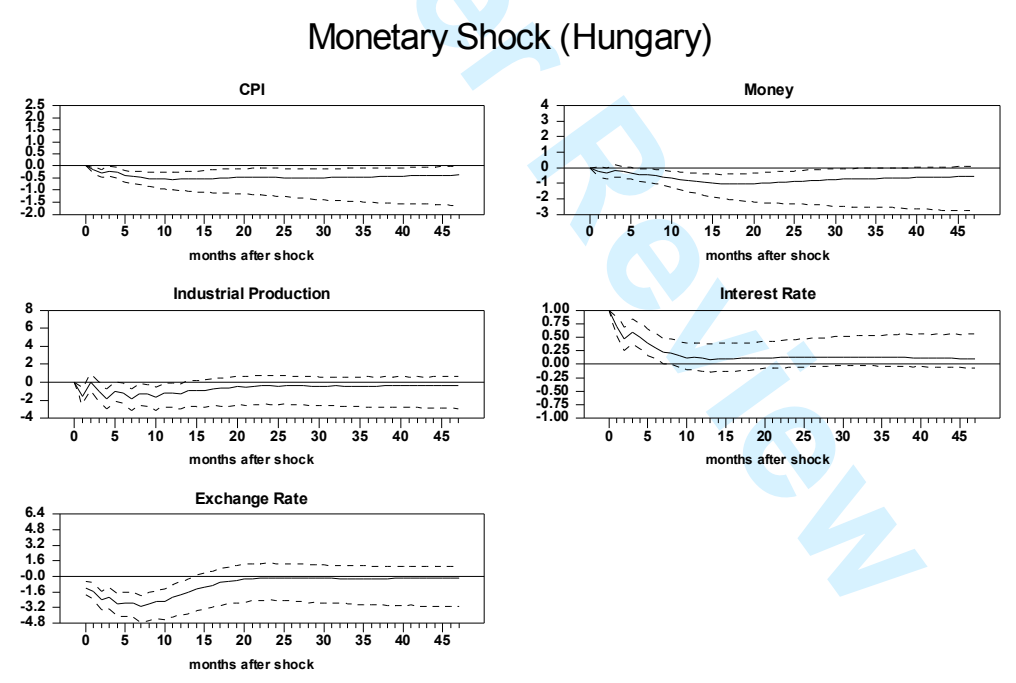

Figure 7: Recursive identification scheme, sample period 1995:04-2002:01 
Monetary Shock (Poland)
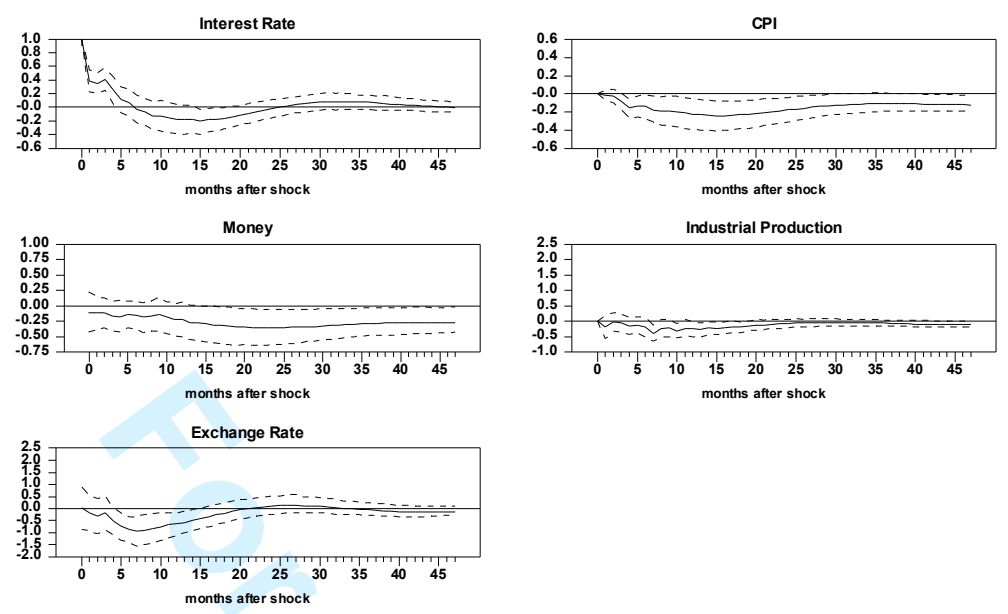

Figure 8: Non-recursive identification scheme, sample period 1993:01-2002:01.

\section{Monetary Shock (Poland)}
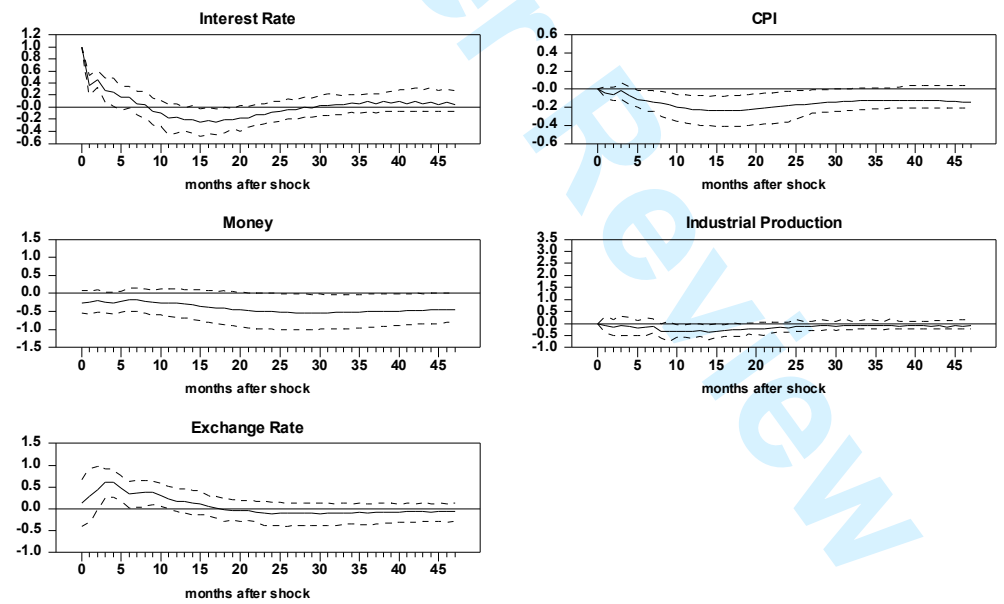

Figure 9: Non-recursive identification scheme, sample period 1993:01-2002:01; real effective exchange rate. 
Monetary Shock (Poland)
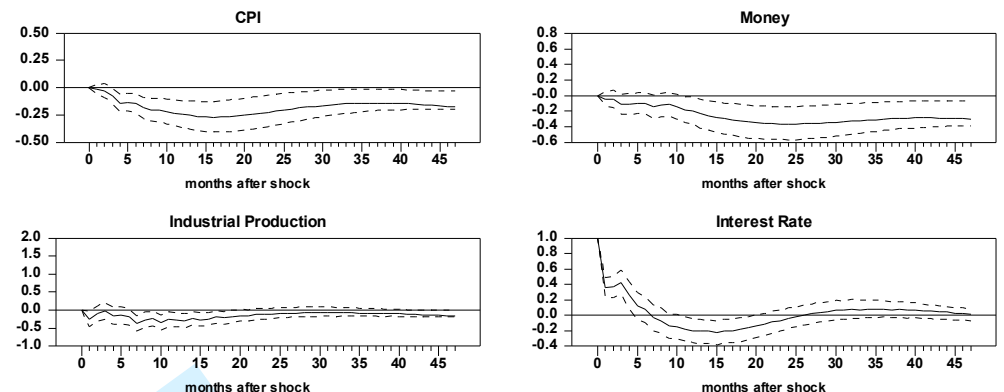

Interest Rate
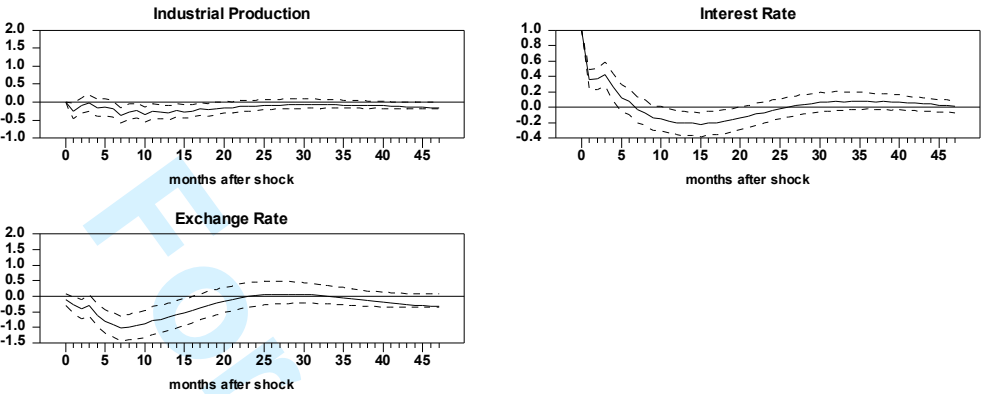

Figure 10: Recursive identification scheme, sample period 1993:01-2002:01.

Table 1: Chronology of exchange rate regimes

$\begin{array}{ll}\text { Czech Rep. } & \text { 1993:01-1997:05 Fixed } \\ & \text { 1997:06-2002:01 Floating } \\ \text { Hungary } & \text { 1993:01-1995:03 Adjustable peg } \\ & \text { 1995:04-2001:04 Crawling peg }( \pm 2.25) \\ & \text { 2001:05-2001:09 Crawling band } \\ & \text { 2001:10-2002:01 Fixed }( \pm 15) \\ & \text { 1993:05-2000:03 Crawling band } \\ \text { Poland } & \text { 2000:04-2002:01 Floating }\end{array}$

Source: Oesterreichische Nationalbank (2002), International Monetary Fund. 
Table 2: Average responses to a $100 \mathrm{bp}$ shock ${ }^{(1)}$

\begin{tabular}{cccc}
\hline \hline & New members & Kim(1999) & Kmand Roubini (2000) \\
\hline output & -1.2 & -1.9 & -1.8 \\
prices & -0.5 & -2.3 & -1.3 \\
\hline \hline
\end{tabular}

(1) The numbers for the new members are the average response of the Czech Republic, Hungary and Poland, while the values reported for Kim (1999) and Kimand Roubini (2000) are the average responses for Germany, France and Italy.

Table 3: Variance decomposition of industrial production due to monetary policy shocks ${ }^{(1)}$

\begin{tabular}{cccccccc}
\hline \hline Step & Ger. & UK & Fr. & It. & Cz.Rep. & Hun. & Pol. \\
\hline 6 & $9.3(4.0)$ & $10.1(3.9)$ & $6.2(3.3)$ & $4.3(3.0)$ & $2.0(3.6 ; 0.6)$ & $12.0(18.8 ; 5.3)$ & $7.5(12.2 ; 2.3)$ \\
12 & $17.9(6.6)$ & $15.3(6.1)$ & $13.9(6.6)$ & $7.1(4.4)$ & $7.3(15.2 ; 1.5)$ & $16.1(25.4 ; 6.9)$ & $13.6(21.9 ; 4.5)$ \\
24 & $23.1(8.5)$ & $11.6(6.3)$ & $17.7(9.9)$ & $8.9(5.2)$ & $11.1(21.4 ; 2.5)$ & $17.8(29.0 ; 7.0)$ & $16.5(27.2 ; 5.8)$ \\
36 & $22.5(8.6)$ & $9.8(5.5)$ & $5.6(9.4)$ & $8.6(4.8)$ & $11.7(22.3 ; 2.9)$ & $18.0(29.5 ; 6.9)$ & $16.9(28.0 ; 6.0)$ \\
48 & $20.4(8.0)$ & $10.1(5.9)$ & $14(8.9)$ & $8.6(4.8)$ & $11.9(22.6 ; 3.0)$ & $18.1(29.8 ; 6.5)$ & $17.3(28.7 ; 6.0)$ \\
\hline \hline
\end{tabular}

(1) For the four largest European economies estimates are those presented in Kim(1999); standard errors in brackets. For the three new members we used estimates obtained using the same variables and the same identification scheme as Kim (1999); fractiles $(84,16)$ are reported in brackets. 